\title{
IRGM wt Allele
}

National Cancer Institute

\section{Source}

National Cancer Institute. IRGM wt Allele. NCI Thesaurus. Code C97238.

Human IRGM wild-type allele is located in the vicinity of $5 q 33.1$ and is approximately $2 \mathrm{~kb}$ in length. This allele, which encodes immunity-related GT Pase family M protein, plays a role in both GTP metabolism and immune responses. A silent mutation in the gene is associated with increased risk of Crohn disease. 